\title{
Pressure tolerance of tadpole larvae of the Atlantic ascidian Polyandrocarpa zorritensis: potential for deep-sea invasion
}

\author{
Paulo Yukio Gomes Sumida*, Arthur Ziggiatti Güth, Miguel Mies
}

\author{
Benthic Dynamics Laboratory (LDB), Department of Biological Oceanography, Oceanographic Institute, Universidade de São Paulo. \\ (Praça do Oceanográfico, 191 - CEP: 05508-120, São Paulo, SP - Brazil) \\ *Corresponding author: psumida@usp.br
}

\begin{abstract}
How deep-sea fauna evolved is a question still being investigated. One of the most accepted theories is that shallow water organisms migrated to deeper waters and gave origin to the deep-sea communities. However, many organisms are prevented from performing long vertical migrations by the increasing hydrostatic pressure. Tadpole larvae of the ascidian Polyandrocarpa zorritensis were submitted to pressure treatments of $1,50,100$ and 200 atm. Survival, settlement and metamorphosis rates were verified after 24 hour incubation in a pressure chamber. The majority of larvae settled (84\%, $62 \%, 83 \%$ and $77 \%$ respectively) and successfully underwent metamorphosis $(93 \%, 59 \%, 85 \%$ and $60 \%)$ in all pressure treatments. Larval mortality was of less than $15 \%$ in all treatments, except for the $50 \mathrm{~atm}$ treatment, which presented 38\% mortality. Nearly $100 \%$ of the surviving larvae underwent metamorphosis in the treatments of 1,50 and 100 atm. However, $1 / 3$ of the individuals were still in their larval stages in the $200 \mathrm{~atm}$ treatment and presented delayed development. These data suggest that ascidian larvae can withstand the hydrostatic pressure levels found in the deep-sea. It is therefore feasible that the current abyssal ascidian species may have colonized the deep-sea through vertical migration and in only a few generations.
\end{abstract}

Descriptors: Deep-sea, Pressure, Tolerance, Ascidian larvae, Polyandrocarpa zorritensis.

\section{Resumo}

Dentre as teorias mais aceitas de como surgiu a fauna de oceano profundo está a de que organismos de águas rasas migraram para águas mais profundas e lá especiaram até originarem as comunidades de mar profundo atuais. No entanto, muitos organismos são impedidos de fazer longas migrações verticais por conta do aumento da pressão hidrostática. Larvas da ascídia Polyandrocarpa zorritensis foram submetidas a pressões de 1, 50, 100 e $200 \mathrm{~atm}$. Taxas de sobrevivência, assentamento e metamorfose foram avaliadas após incubação de 24 horas em uma câmara de pressão. A maioria das larvas assentou (84\%, $62 \%, 83 \%$ e $77 \%$, respectivamente) e completou a metamorfose $(93 \%, 59 \%, 85 \%$ e $60 \%)$ em todas as pressões. A mortalidade ficou abaixo de $15 \%$ para todas as pressões, com exceção do tratamento de $50 \mathrm{~atm}$, em que a mortalidade ficou em 38\%. Quase $100 \%$ das larvas sobreviventes completaram a metamorfose nos tratamentos de 1,50 e $100 \mathrm{~atm}$. No entanto, para o tratamento de $200 \mathrm{~atm}, 1 / 3$ dos indivíduos ainda estavam no desenvolvimento larval e apresentaram um desenvolvimento atrasado. Esses resultados sugerem que larvas de ascídia podem suportar valores de pressão hidrostática que são encontrados no oceano profundo. Portanto, é provável que as atuais espécies de ascídias de oceano profundo podem tê-lo colonizado por meio de migrações verticais em algumas gerações.

Descritores: Oceano profundo, Pressão, Tolerância, Larva de ascídia, Polyandrocarpa zorritensis. 
Whether the deep-sea fauna sprang from ancestors within the deep-sea or instead from multiple invasions of shallow water species is a question that has yet to be answered (TYLER; YOUNG, 1992; TYLER; YOUNG, 1998; BROWN; THATJE, 2014). Factors affecting the successful colonization of deeper waters are mainly physical, including advection to suitable areas and temperature and pressure tolerances (SMITH; THATJE, 2012). An invasion of the deep-sea likely occurred when the water column was less stratified, allowing longer vertical migrations to take place (MENZIES et al., 1973; HESSLER; WILSON, 1983). For that scenario, the temperature could have been similar to either the cold conditions currently found in higher latitudes or the reported warm conditions during the Paleocene-Eocene Thermal Maximum approximately 55 million years ago (TRIPATI; ELDERFIELD, 2005) and found today in the Mediterranean sea.

Increased pressure can be deleterious to various early stages in the life cycle of many neritic and shallow water ( $i$. e., depths lower than $200 \mathrm{~m}$ ) inhabitants (PRADILLON, 2012), such as described for the oocytes of the polychaete Chaetopterus sp. (SALMON, 1975) and also for the embryos of the sea urchin Psammechinus miliaris (AQUINO-SOUZA et al., 2008). However, some early dispersal stages from shallow water organisms are known to withstand high pressure and have been reported as possible deep-sea colonizers, such as is the case of the Atlantic asteroids Asterias rubens and Marthasterias glacialis (VILLALOBOS et al., 2006), the Antarctic sea urchin Sterechinus neumayeri (TYLER et al., 2000) and the gastropods Crepidula fornicata (MESTRE et al., 2013) and Buccinum undatum (SMITH; THATJE, 2012). Furthermore, it has been documented that both shallowand deep-water populations of the sea urchin Echinus acutus present embryonic and larval pressure tolerances in agreement with those required for a current invasion of the deep-sea by this species (TYLER; YOUNG, 1998). Some species of adapted shallow water organisms therefore have the potential to invade the deep-sea through larval migration and dispersal.

For a shallow-water organism invasion to be successful, the larvae of such organisms must then metamorphose under high pressure. While this ability has been detected in some echinoderms and gastropods, it has never been observed in other taxa. We chose a chordate as a model organism for the investigation of potential deep-sea invasion as they can be very diverse and abundant in the deep-sea (MONNIOT, 1998; MECHO et al., 2014). Ascidians are good test organisms because they comprise a group easily bred in captivity and have a brief lecithotrophic larval stage (SVANE; YOUNG, 1989), as well as wide horizontal distribution across the oceans. We investigated the capability of larvae of the compound ascidian Polyandrocarpa zorritensis (VAN NAME, 1931) (Tunicata: Styelidae) to develop normally and successfully metamorphose while withstanding high hydrostatic pressure. We also tested for the occurrence of possible delays in the development of larvae exposed to different pressure levels.

Colonies of the non-native temperate ascidian brooder Polyandrocarpa zorritensis were collected in the intertidal zone at the Fort Pierce Marina in Florida, USA (ca. $27^{\circ}$ $27^{\prime} \mathrm{N}$ and $80^{\circ} 19^{\prime} \mathrm{W}$ ) during summer. Specimens were transferred to the laboratory and maintained in a holding tank at $23^{\circ} \mathrm{C}$ with flow-through seawater. Release of brooded larvae was induced by exposing adult colonies to bright sunlight (WATANABE; LAMBERT, 1973; VÁZQUEZ; YOUNG, 1998). Swimming tadpoles were collected and placed in beakers at the same temperature as the holding tank that contained the adult colonies. Ten tadpoles of $P$. zorritensis were then incubated in 10 $\mathrm{mL}$ plastic scintillation vials containing $0.2 \mu \mathrm{m}$ filtered seawater and kept at a density of 1 tadpole mL-1. One set of four replicate experiments was placed in one of four different stainless steel pressure vessels at 1 (control pressure), 50, 100 and $200 \mathrm{~atm}$, simulating the pressure found at depths of $0,500,1,000$ and 2,000 m, respectively. Temperature was kept stable at $23^{\circ} \mathrm{C}$. After 24 hours of incubation, the mortality, settlement and metamorphosis of tadpoles were observed and analyzed. The development of tadpoles was classified in five different stages using tail resorption as a proxy for metamorphosis (HADFIELD et al., 2001); these categories were not metamorphosed (early tadpole, stage T), 25\% tail resorption (stage A), $50 \%$ (stage B), $75 \%$ (stage C) and fully metamorphosed without any vestiges of the tail (juvenile, stage J). The proportions of successful metamorphosis, settlement, mortality and developmental stage attained were assessed through contingency tables for each pressure treatment. Pearson's Chi-squared test was performed to check the statistical significance among these proportions.

Brooded larvae of Polyandrocarpa zorritensis were released soon after light stimuli. The majority of larvae settled and underwent metamorphosis in all pressure treatments during the $24 \mathrm{~h}$ incubation period (Table 1). No 
significant difference was found in the number of ascidian larvae that successfully achieved settlement under the tested pressures of $1,50,100$ and 200 atm $\left(\chi^{2}=6.65\right.$; d.f. $=3 ; p$ $=0.083)$. The highest level of mortality was observed at 50 atm $\left(\chi^{2}=14.60\right.$; d.f. $\left.=3 ; p=0.0022\right)$, with a mean value of $38 \%$. The mortality rate remained below $15 \%$ for the 1 , 100 and 200 atm pressure vials and no significant statistical difference related to mortality was found among them.

Table 1. Metamorphosis, settlement and mortality rates for Polyandrocarpa zorritensis larvae incubated at four different pressure levels.

\begin{tabular}{lccc}
\hline $\begin{array}{l}\text { Pressure level } \\
\text { (atm) }\end{array}$ & $\begin{array}{c}\text { Successful } \\
\text { metamorphosis }\end{array}$ & Settlement & Mortality \\
\hline 1 & $0.93 \pm 0.15$ & $0.84 \pm 0.17$ & $0.08 \pm 0.15$ \\
50 & $0.59 \pm 0.10$ & $0.62 \pm 0.12$ & $0.38 \pm 0.12$ \\
100 & $0.85 \pm 0.13$ & $0.83 \pm 0.12$ & $0.15 \pm 0.13$ \\
200 & $0.60 \pm 0.17$ & $0.77 \pm 0.28$ & $0.08 \pm 0.11$ \\
\hline
\end{tabular}

Nearly all the individuals had completed metamorphosis (Stage J) after $24 \mathrm{~h}$ for the pressures of 1, 50 and $100 \mathrm{~atm}$. However, $33 \%$ of the individuals were still in their larval development under the $200 \mathrm{~atm}$ treatment (Figure 1).

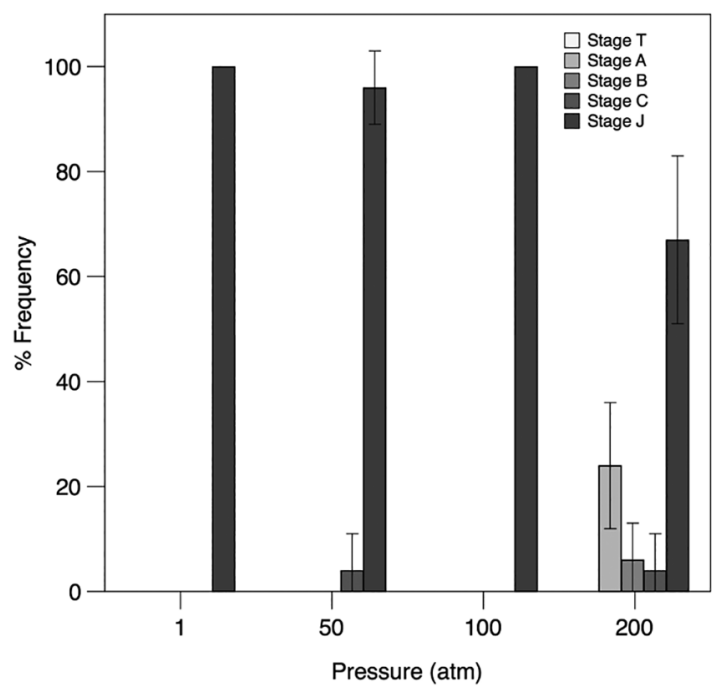

Figure 1. Frequencies of different ontogenetic stages attained by live Polyandrocarpa zorritensis individuals after incubation at 1,50,100 and $200 \mathrm{~atm}$ for 24 hours. Stages are T - early tadpole; A - 25\% tail resorption; B - 50\% tail resorption; C - 75\% tail resorption; and $\mathrm{J}$ complete tail resorption, juvenile.

Many shallow water adult organisms are known to cope with increasing levels of hydrostatic pressure, such as in palaemonid shrimps (OLIPHANT et al., 2010) and hermit crabs (THATJE et al., 2010). However, that number decreases significantly when the tested organisms are still undergoing larval development (MESTRE et al., 2009). Our results show that the larvae of Polyandrocarpa zorritensis were resilient to increased pressure and metamorphosed successfully under such conditions (Table 1, Figure 1). It is expected that intense hydrostatic pressure could negatively affect survival rates of ascidian larvae given the substantial physiological change that occurs at metamorphosis, such as the rotation of organs, the expansion, elongation or reciprocation of ampullae (CLONEY, 1978) and significant cell and tissue differentiation (DAVIDSON; SWALLA, 2002). CLONEY (1971) also reports that the tadpoles of the aplousobranch ascidian Distaplia occidentalis fail to contract the caudal epidermis at pressures above $400 \mathrm{~atm}$.

However, pressure seemed to have no influence on the survival of tadpoles in this experiment. Most of the $P$. zorritensis larvae settled and metamorphosed successfully at all the pressures examined (Figure 1). Mortality was low, especially at 200 atm which was equivalent to that of control pressure treatment (Table 1). Overall, the experiments demonstrated that ascidian larvae are capable of developing normally under pressure conditions found at 2,000 m. While the development was normal at this pressure, one third of the individuals had still not undergone metamorphosis after $24 \mathrm{~h}$ incubation (Figure 1). This suggests that the time for development may be slightly longer for individuals at pressures $\geq 200 \mathrm{~atm}$.

Ascidian larvae are known to behave either by actively swimming or by passively drifting (YOUNG, 1986; ZEGA et al., 2006) and perform daily vertical migrations (VÁZQUEZ; YOUNG, 1996). It has been shown that the average swimming speed of the tadpoles of eleven ascidian species is $1.0 \mathrm{~cm} \mathrm{~s}^{-1}$ (BERRILL, 1931), which would account for a migration of $864 \mathrm{~m}$ daily if the larvae swam constantly in only one direction. MCHENRY and PATEK (2004) created a model to estimate the swimming speed of ascidian tadpoles based on trunk radius, trunk volume and tail length. Using the dimensions of a P. zorritensis tadpole, approximately $0.25 \mathrm{~mm}$ for the trunk radius, $0.065 \mathrm{~mm} 3$ for trunk volume and $1.3 \mathrm{~mm}$ for tail length, the estimated speed is of $4.0 \mathrm{~mm} \mathrm{~s}^{-1}$; this would account for a migration of $350 \mathrm{~m}$ daily. Along with other ascidian species, $P$. zorritensis is known to occur in the North Atlantic and in the Mediterranean (BRUNETTI; MASTROTARO, 2004), sites that are known to aid in deepwater formation (PICKART et al., 2003). Thermohaline circulation could therefore aid large-scale vertical migrations. Considering 
that larval development for ascidians may range between 1 and 10 days (KANARY et al., 2011), it is possible that ascidian larvae could have colonized the deep-sea in a very few generations, especially if the development is delayed as shown by our results. Therefore, it is feasible that some of the 124 known abyssal ascidian species (MONNIOT et al., 1976; LAMBERT, 2005) could have colonized the deep-sea through migration. Temperature is not expected to act as a barrier, as $P$. zorritensis and other ascidians (e.g., Styela clava, Didemnum vexillum) are known to withstand both temperature fluctuations of more than $20^{\circ} \mathrm{C}$ and low winter temperatures (BRUNETTI, 1978-79; LAMBERT; LAMBERT, 1998; 2003).

Our results suggest that the larvae of the ascidian $P$. zorritensis are capable of tolerating pressure variations that prevent many organisms from migrating deep into the ocean. Furthermore, the duration of the tadpole stage may be extended by the delay in metamorphosis when the larvae are exposed to increased pressure. This study may contribute to the better comprehension of the origins of deep-sea fauna and of the possibility of new invasions by non-indigenous species. Placed in a broader ecological context, the information on pressure tolerance can aid in the current understanding of the ecology of such invertebrates, as well as their physiological responses to those conditions.

\section{ACKNOWLEDGEMENTS}

The authors wish to thank Dr. L Waters for reviewing the manuscript.

\section{REFERENCES}

AQUINO-SOUZA, R.; HAWKINS, S. J.; TYLER, P. A. Early development and larval survival of Psammechinus miliaris under deep-sea temperature and pressure conditions. J. Mar. Biol. Ass. U. K., v. 88, n. 3, p. 453-461, 2008.

BERRILL, N. J. Studies in tunicate development. Part II. Abbreviation of development in the Molgulidae. Philos. Trans R. Soc. Lond B. Biol., v. 219, p. 281-346, 1931.

BROWN, A.; THATJE, S. Explaining bathymetric diversity patterns in marine benthic invertebrates and demersal fishes: physiological contributions to adaptation of life at depth. Biol. Rev. Camb. Philos. Soc., v. 89, n. 2, p. 406-426, 2014.

BRUNETTI, R. Polyandrocarpa zorritensis (Van Name, 1931) a colonial ascidian new to the Mediterranean record. Vie Milieu, v. 28-29, p. 647-652, 1978-1979.

BRUNETTI, R.; MASTROTOTARO, F. The non-indigenous stolidobranch ascidian Polyandrocarpa zorritensis in the Mediterranean: description, larval morphology and pattern of vascular budding. Zootaxa, v. 528, p. 1-8, 2004.
CLONEY, R. A.; LASH, J. A.; MINOR, R. R. Ascidian metamorphosis: Contractile tissues, cytochalasin $\mathrm{B}$ and hydrostatic pressure. Biol. Bull., v. 141, p. 382, 1971.

CLONEY, R. A. Ascidian metamorphosis: review and analysis. In: CHIA, F. S.; RICE, M. E. (Eds.). Settlement and metamorphosis in marine invertebrate larvae. New York: Elsevier, 1978. p. 255-282.

DAVIDSON, B.; SWALLA, B. J. A molecular analysis of ascidian metamorphosis reveals activation of an innate immune response. Development, v. 129, n. 20, p. 4739-4751, 2002.

HADFIELD, M. G.; CARPIZO-ITUARTE, E. J.; DEL CARMEN, K.; NEDVED, B. T. Metamorphic competence, a major adaptive convergence in marine invertebrate larvae. Am. Zool., v. 41, n. 5, p. 1123-1131, 2001.

HESSLER, R. R.; WILSON, G. D. F. The origin and biogeography of malacostracan crustaceans in the deep sea. In: SIMS, R.W.; PRICE, J. H.; WHALLEY, P. E. S. (Eds.). Evolution in time and space: the emergence of the biosphere. New York: Academic Press, 1983. p. 227-254.

KANARY, L.; LOCKE, A.; WATMOUGH, J.; CHASSÉ, J.; BOURQUE, D.; NADEAU, A. Predicting larval dispersal of the vase tunicate Ciona intestinalis in a Prince Edward Island estuary using a matrix population model. Aquat. Invasions, v. 6, n. 4, p. 491-506, 2011.

LAMBERT, G. Ecology and natural history of the protochordates. Can. J. Zool., v. 83, n. 1, p. 34-50, 2005.

LAMBERT, C. C.; LAMBERT, G. Non-indigenous ascidians in southern California harbors and marinas. Mar Biol., v. 130, n. 4, p. 675-688, 1998

LAMBERT, C. C.; LAMBERT, G. Persistence and differential distribution of nonindigenous ascidians in harbors of the Southern California Bight. Mar. Ecol. Prog. Ser., v. 259, p. 145-161, 2003.

MCHENRY, M. J.; PATEK, S. N. Evolution of larval morphology and swimming performance in ascidians. Evolution, v. 58, n. 6, p. 1209-1224, 2004.

MECHO, A.; AGUZZI, J.; COMPANY, J. B.; CANALS, M.; LASTRAS, G.; TURON, X. First in situ observations of the deep-sea carnivorous ascidian Dicopia antirrhinum Monniot C., 1972 in the Western Mediterranean Sea. Deep Sea Res. Part I Oceanogr. Res. Pap., v. 83, p. 51-56, 2014.

MENZIES, R. J.; GEORGE, R. Y.; ROWE, T. Abyssal environment and ecology of the World Oceans. New York: Wiley Interscience, 1973.

MESTRE, N. C.; BROWN, A.; THATJE, S. Temperature and pressure tolerance of the larvae of Crepidula fornicata suggest thermal limitation of bathymetric range. Mar. Biol., v. 160, n. 4 , p. 743-750, 2013.

MESTRE, N. C.; THATJE, S.; TYLER, P. A. The ocean is not deep enough: pressure tolerances during early ontogeny of the blue mussel Mytilus edulis. Proc. Biol. Sci., v. 276, n. 1657, p. 717-726, 2009.

MONNIOT, C. Abyssal ascidians collected from the proximity of hydrothermal vents in the Pacific Ocean. Bull. Mar. Sci., v. 63, n. 3, p. 541-558, 1998.

MONNIOT, C.; MONNIOT, F.; MILLAR, R. H. An account of six species of abyssal Styelidae (Ascidiacea), three of which are new species. Deep Sea Res., v. 23, n. 12, p.1187-1197, 1976. 
OLIPHANT, A.; THATJE, S.; BROWN, A.; MORINI, M.; RAVAUX, J.; SHILLITO, B. Pressure tolerance of the shallow-water caridean shrimp Palaemonetes varians across its thermal tolerance window. J. Exp. Biol., v. 214, n. Pt 7, p. 1109-11017, 2010.

PICKART, R. S.; SPALL, M. A.; RIBERGAARD, M. H.; MOORE, G. W. K.; MILLIFF, R. F. Deep convection in the Irminger Sea forced by the Greenland tip jet. Nature, v. 424, p. $152-156,2003$.

PRADILLON, F. High hydrostatic pressure environments. In: BELL, E. M. (Ed.). Life at Extremes: Environments, Organisms and Strategies for Survival. Wallingford: $\mathrm{CAB}$ International, 2012. p. 271-95.

SALMON, E. D. Pressure-induced depolymerization of spindle microtubules: 1. Changes in birefringence and spindle length. J. Cell Biol., v. 65, n. 3, p. 603-614, 1975.

SMITH, K. E.; THATJE, S. The Secret to Successful Deep-Sea Invasion: Does Low Temperature Hold the Key? PLoS ONE, v. 7, n. 12, p. e51219, 2012.

SVANE, I.; YOUNG, C. M. The ecology and behaviour of ascidian larvae. Oceanogr. Mar. Biol., v. 27, p. 45-90, 1989.

THATJE, S.; CASBURN, L.; CALCAGNO, J. A. Behavioural and respiratory response of the shallow-water hermit crab Pagurus cuanensis to hydrostatic pressure and temperature. J. Exp. Mar. Biol. Ecol., v. 390, n. 1, p. 22-30, 2010.

TRIPATI, A.; ELDERFIELD, H. Deep-sea temperature and circulation changes at the Paleocene-Eocene Thermal Maximum. Science, v. 308, p. 1894-1898, 2005.

TYLER, P. A.; YOUNG, C. M. Reproduction in marine invertebrates in "stable" environments: the deep-sea model. Invertebr. Reprod. Dev., v. 22, n. 1/3, p. 185-192, 1992.
TYLER, P. A.; YOUNG, C. M. Temperature and pressure tolerances in dispersal stages of the genus Echinus (Echinodermata: Echinoidea): prerequisites for deep-sea invasion and speciation. Deep Sea Res. Part II Top. Stud. Oceanogr., v. 45, n. 1/3, p. 253-277, 1998.

TYLER, P. A.; YOUNG, C. M.; CLARKE, A. Temperature and pressure tolerances of embryos and larvae of the Antarctic sea urchin Sterechinus neumayeri (Echinodermata: Echinoidea): potential for deep-sea invasion from high latitudes. Mar. Ecol. Prog Ser., v. 192, p. 173-180, 2000.

VÁZQUEZ, E.; YOUNG, C. M. Responses of compound ascidian larvae to haloclines. Mar. Ecol. Prog. Ser., v. 133, n. 3/1, p. 179-190, 1996.

VÁZQUEZ, E.; YOUNG, C. M. Ontogenetic changes in phototaxis during larval life of the Ascidian Polyandrocarpa zorritensis (Van Name, 1931). J. Exp. Mar. Biol. Ecol., v. 231, n. 2, p. 267-277, 1998.

VILlalobos, F. B.; TYleR, P. A.; YOUNG, C. M. Temperature and pressure tolerance of embryos and larvae of the Atlantic seastars Asterias rubens and Marthasterias glacialis (Echinodermata: Asteroidea): potential for deep-sea invasion. Mar. Ecol. Prog. Ser., v. 314, p. 109-117, 2006.

WATANABE, H.; LAMBERT, C. C. Larva release in response to light by the compound ascidians Distaplia occidentalis and Metandrocarpa taylori. Biol. Bull., v. 144, p. 556-566, 1973.

YOUNG, C. M. Direct observations of field swimming behavior in larvae of the colonial ascidian Ecteinascidia turbinata. Bull. Mar. Sci., v. 39, n. 2, p. 279-289, 1986.

ZEGA, G.; THORNDYKE, M. C.; BROWN, E. R. Development of swimming behaviour in the larva of the ascidian Ciona intestinalis. J. Exp. Biol., v. 209, n. Pt 17, p. 3405-3412, 2006. 
